DOI: $\underline{\text { https://doi.org/10.34069/AI/2021.42.06.19 }}$

How to Cite:

Tigrov, V., Tolstenko, A., Negrobova, L., Dobromysl ova, O., \& Piminov, E. (2021). Education, work and creation: ways for developing technological education of schoolchildren in Russia. Amazonia Investiga, 10(42), 206-216. https://doi.org/10.34069/AI/2021.42.06.19

\title{
Education, work and creation: ways for developing technological education of schoolchildren in Russia
}

\section{Образование, труд и творчество: пути развития технического образования среди школьников в России}

Received: June 7, 2021

\begin{abstract}
The authors touch upon the problem of the development of additional technological education in Russian schools by comparing it with the situation in Western countries. Aim: strong requirements for inventions of schoolchildren should be established, a clear sequence of their teaching in invention and creation should be developed. Methods: methodology for teaching schoolchildren to invent and create something that has not existed before in different age groups is presented; a patent for a utility model developed jointly with schoolchildren participating in the system of additional technological education in Lipetsk seem to be important results of this study. Results: the authors considered ways to improve the effectiveness of teaching schoolchildren to invent in the field of additional technological education, taking into account current problems and trends. The systematic training of schoolchildren from elementary grade to middle and senior grades normally gives a positive result during the formation of
\end{abstract}

\footnotetext{
85 (Prof., DSc), Lipetsk of State Pedagogical University, Russia.

86 (Docent, DSc), Lipetsk of State Pedagogical University, Russia.

87 (Senior Lecturer), Lipetsk of State Pedagogical University, Russia.

88 (Senior Lecturer), Lipetsk of State Pedagogical University, Russia.

89 (Senior Lecturer), Lipetsk of State Pedagogical University, Russia.
}

Accepted: July 15, 2021

$$
\begin{array}{r}
\text { Written by: } \\
\text { Vyacheslav Tigrov } \\
\text { hs } \\
\text { https://orcid.org/0000-0002-8115-994X } \\
\text { Andrew Tolstenko } \\
\text { ht } \\
\text { htps://orcid.org/0000-0001-5611-9113 } \\
\text { Ludmila Negrobova } \\
\text { https://orcid.org/0000-0003-1765-5110 } \\
\text { Olga Dobromyslova } \\
\text { hts } \\
\text { htps://orcid.org/0000-0002-6060-6691 } \\
\text { Evgeny Piminov }^{89} \\
\text { https://orcid.org/0000-0002-9634-4021 }
\end{array}
$$

проблему развития дополнительного технологического
образования в российских школах, сравнивая ее с ситуацией в западных странах. Цель: установить четкие требования к изобретениям школьников, разработать четкую последовательность их обучения изобретательству и творчеству. Методы: представлена методика обучения школьников изобретательству в разных возрастных группах; патент на полезную модель, разработанный совместно со школьниками, участвующими в системе дополнительного технологического образования г. Липецка, также представляется важным результатом исследования. Результаты: авторами рассмотрены пути повышения эффективности обучения школьников изобретательству в сфере дополнительного технологического образования с учетом актуальных проблем и тенденций. Систематическая подготовка школьников от начального до среднего и старшего классов 


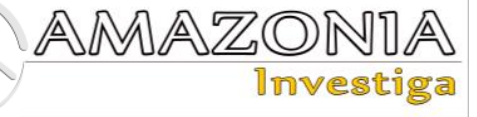

divergent thinking, which translates into the child's ability to generate a variety of ideas for improving technical objects and creation as such. Attracting the capabilities of enterprises to organize an authentic educational process is relevant, too, as long as the project activities are designed to form the skills of independent work, creative and research activities.

Keywords: creation, invention, metaphysics of technology, technological education, school. обычно дает положительный результат при формировании дивергентного мышления, что выражается в способности ребенка генерировать различные идеи для улучшения технических объектов. Привлечение возможностей предприятий для организации аутентичного образовательного процесса весьма актуально, поскольку проектная деятельность направлена на формирование навыков самостоятельной работы, творческой и исследовательской деятельности.

Ключевые слова: творчество, изобретение, метафизика техники, технологическое образование, школа.

\section{Introduction}

As the history of many countries shows, in any era, the society technological progress is inextricably connected both to the technical capabilities in a specific time period and with the need for training specialists who are able to generate novel ideas aimed at improving the devices and technologies used, and to develop something principally new, opening previously unknown technological vectors. In this respect Russia is no exception, and as any state is faced with the need to meet the requirements of the time, to take dynamic actions to develop technologies in general, and to train specialists in demand in various areas of production in particular. The experience indicates that the training of future workers in the technical sphere is a strategic issue that determines the dynamism of the country's development, its success in the world market and the ability to export both technical innovations and marketable as well as significant production technologies, showing its own competitiveness and independence. In this regard, an objective fact can be considered the need for technological training of future specialists at all levels of education, starting from school age, and involving the system of compulsory and extracurricular education for this. As philosophers say, technology is the most important way to discover the deepest properties of human being (Mitcham, 1994; Skrbina, 2014). It allows you to reveal what is hidden in him, must be guessed and presented in a genuine face. In acts of technical creativity, people realize contact with transcendental "things-in-themselves" of technical objects. Consciousness enters the metaphysical level and encounters the realm of given solutions to technical problems. The mind picks up technical ideas, which are something like the thoughts of
God. That is, technology is the real participation of man in creation. From a theological perspective, technology is a mission, a mandate from a Creator who uses a person to realize his own purposes (Dessauer, 1956). The idea of technology, which we are accustomed to perceive as something rigid, rational, soulless, having nothing to do with spiritual truths, was formed quite recently. A century ago, as well as thirty centuries ago, people saw in technology an act of pure spiritual creativity (Dessauer, 1983). According to Heidegger, a person transforms things, transferring them from the state of "availability" to the state of "handiness" (Heidegger, 1977). Technique grows out of natural material, but it enters into the existential structure of human being, who has the ability to object to his designs. Technique, according to Heidegger, goes deep into the realm of truth. The technical is not a consumer attitude, like the idea that it is necessary to "take", to take everything as if it already exists only for that purpose, as if there is no secret of creation. Instead of seeing technology as a means for turning everything (including ourselves) into resources, one should see technology as art. In reality, the technical contains something of art. Craftsmanship is a way of revealing the hidden, something fateful for human survival and that cannot be reduced to mass production. That is why a realignment of people's thinking is required to overcome the modern crisis tendencies. The severity of the above problem was recognized at all times of state existence, in connection with which actions were taken in the education system to develop the line of technological learning (Dessauer, 1959). Thus, the purpose of the research is to form a model of current technological education of schoolchildren within the educational concept 
being implemented (strong requirements for inventions of schoolchildren and a clear sequence of their teaching in invention and creation), taking into account the identified trends and prerequisites for further development.

\section{Literature Review}

Our study covers the analysis of the state of technological education in the last decades of the recent history of Russia, since this period becomes a platform for the current stage of its development. The relevance of the above is especially noticeable at the present time in connection with accelerating technical progress and growing "uncertainty" in the life of individual citizens and society as a whole, which leads to the need to transform the existing "industrial" paradigm of education, and its adaptation to conditions of new time (Ankiewicz, 2019; Ardura and Pérez-Bitrián, 2019; Susanto, Rachmadtullah and Rachbini, 2020; Tolstenko, Baltovskij and Radikov, 2019). In general, drawing parallels between the development history and the current state of technological education in Russia in relation to other states, we can talk about similar trends. Firstly, meeting the today's requirements, many countries are reforming the education system, and one of the mandatory subject is the "technology", the task of which is to form students' competencies that are relevant for the developing technological civilization (Botleng, Brunel and Girard, 2019; Bushueva and Bushuev, 2018; Chai, Jong, Yin, Chen and Zhou, 2019; Cropley and Cropley, 2010; Hrybiuk, 2019). Secondly, an objective feature of the development of technological education in different countries is the reforms implementation taking into account the wellknown pedagogic principles of natural conformity, cultural conformity, continuity and gradation. In accordance with them, the complexity of school technological education programs increases from the initial level, where acquaintance with simple mechanisms and technologies occurs to the middle and senior level, where the tasks are the mastering of advanced technologies of various industries, the use of computer technologies and the formation of competencies necessary for adaptation in modern process environment. And training programs are built as part of guidelines for national-specific features and foundations, cultural traditions and branches of the public economy (Ihde, 2006; Skytt-Larsen, 2018; Sundqvist, 2020). Thirdly, the modern educational sphere of different countries in general, and the system of training in the sphere of technology in particular, are faced with the following obvious contradiction. On the one hand, the modern system is still based on the "industrial" educational paradigm, in accordance with which teaching is standardized and oriented towards conformism (Solé Blanch, 2020). On the other hand, in the conditions of a progressive "situation of uncertainty" of the recent epoch, a person is required to have divergent thinking, which must be taught, and as a result of which a person will be able to put forward and implement not only standard solutions to known problems, but will creatively rethink them and, when run into problems, suggest a variety of options for their solution (Danilaev and Malivanov, 2020; Nigmatov and Nugumanova, 2015; Smirnova, 2018). To successfully overcome such contradictions in future development of the field under consideration, an "education paradigm shift" will be required (Dakers, 2006). Herewith, existing in the given conditions, the education systems of different countries shall provide the society with the required result already now, within the existing paradigm, which gives rise to the need to revise the resources available to teachers and involve all existing opportunities. It is necessary to take into account the significant conservatism of the pedagogic system associated with its location on previous experience and national cultural traditions, which requires a careful and attentive approach. Otherwise, one may lose the old without forming the new. And then the educational sphere may meet with an even deeper crisis depersonalization (Tigrov and Negrobova, 2018; Tolstenko, Baltovskij, Radikov, 2019; Kondratiev, Rudneva, Tolstenko, 2021).

\section{Methodology}

How should the technological education system change in the nearest future based on the aforesaid? We see that new requirements are imposed on education for workers capable of innovative activities with the active progress of society and the production development (Duggan, 1996; Thayer-Bacon, 2019). That is, specialists of the recent and future time must have "thinking divergence" and competencies, both in the field of ideas generation and in the sphere of their execution and practical implementation (Hursen, 2017). Whereby, the wishes regarding the process and the final result of schoolchildren teaching change (Portnova, 2016): the child must be taught the activity bases, the product of which is the development of objects having innovative potential 


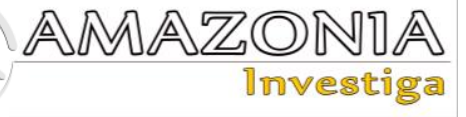

(Hallström, 2020; McLain, Irving-Bell, Wooff and Morrison-Love, 2019). And then, one of the important spheres, where such quality can be formed, is a technological education. Moreover, since school education is rather rigidly standardized, to a greater extent such prospects are implemented in the system of extracurricular technological education, which is not so strictly bound by the framework. As a result, it is here where it is possible to form the necessary competencies and successfully solve the above tasks within the existing paradigm, teaching schoolchildren to invention.

The material for the theoretical study was data on the development of the technological education system in the 20th century in the USSR and the Russian Federation (papers by Kachnev, 1990, Kaner, 2016, Kolotilov, 1989, Nikulin, 1994), as well as the similar papers of foreign colleagues. The experimental part was carried out based on the Center for Youth Innovative Creativity "Novator" (CMIT Novator) in Lipetsk, which belongs to the extracurricular education system. During the work, the following methods were used:

a. Analysis of the goals and forms of extracurricular technological education for schoolchildren at different stages of its development in the 20th century and identification of the main problems in the area under consideration; identification of trends in its further development with the definition of the respective prerequisites.

b. Development of content, choice of forms, determination of the sequence of schoolchildren teaching to inventive work in the system of extracurricular technological education, taking into account the identified problems and trends.

c. Implementation of activities (classroom studies and excursions to production facilities) to teach schoolchildren to invention, taking into account the identified prerequisites; analysis of the results obtained.

The practical part carried out during the study included the following stages: 1) development of training content, selection of forms and methods of work; 2) involvement of schoolchildren to inventive work and forming of student groups; 3) work on teaching schoolchildren with subsequent presentation of materials at exhibition sites, patenting of inventions.

\section{Results}

(1) Within the current study on the organization of schoolchildren teaching invention based on the platform of extracurricular school education, it was found that the essential components of the pedagogical model of current technological education of schoolchildren should be the following: students mastering of methods for activation of decision making in creative problems that form the methodological toolkit of the future inventor; the availability of advanced equipment that makes it possible to practically implement inventive ideas and reduce the time for actions performed; close relationship of students with the enterprises of the region, giving an idea of specific industries, their equipment, process and products, as well as the range of technical problems to be solved. An important trend in teaching students in this context is the allocation of a small time share to mastering "manual" process operations at the initial stages of training, and the active mastering of work with complex process equipment in senior classes; and the desired result is the schoolchildren ability to create objects both with subjective and objective novelty (Sasova, 2011).

(2) The study made it possible to identify several groups of prerequisites that allow transferring technological education to a new level, where the schoolchildren education will result in the development of inventive skills and the ability to produce objects with objective novelty. In our opinion, the very need of transition to innovative project activities in the sphere of technological education of children and teen-agers dictated by the time and the current stage of society development belongs to the first group of prerequisites. In this regard, it is necessary to understand that with the accelerating technical progress, the range of tasks to be solved in the technological sphere will constantly grow. And for a competent specialist, important skills are, firstly, the ability to see such a problem, secondly, to propose ways to solve it, and thirdly, to find opportunities to implement the proposed ideas into production. The second group of prerequisites is the presence of widely known and well-proven methods for activation of creative activity, such as the theory of inventive problem solution, brainstorming, synectics, etc. (Gordon, Aber and Berliner, 2012; Nesterenko and Terekhova, 2017). An important aspect for students herein is the availability of information sources that provide knowledge both on paper and in the form of electronic media. The third 
group of prerequisites is the availability of advanced high-tech equipment for students. It is possible to organize the work of schoolchildren with such equipment through provision of workshops and laboratories of educational institutions, and in the course of cooperation with organizations and enterprises that have the necessary appliances. This will provide opportunities both for studying the technical equipment of the region's production facilities, and for implementing inventive ideas, and, at the same time, saving the inventor's time. The fourth most important prerequisite is the possibility for schoolchildren to get in contact with the enterprises in the real sector of the economy, including the organization of excursions to production facilities and remote online communication.

(3) We implement the practical stage of the presented study based on the Center for Youth Innovative Creativity "Novator" (CMIT Novator) in Lipetsk, where groups of children studying invention are formed annually. Moreover, there is a steady interest of children and parents in the development of invention skills in schoolchildren, which makes it possible to easily form groups of both the initial and subsequent stages of education. The experience of this activity has shown that work related to schoolchildren teaching the invention can cover all age groups, from primary grades to senior ones, which makes it possible to build educational trajectories (paths) of schoolchildren in this sphere in the system of continuous education. This made it possible to determine the syllabus and the sequence of its implementation at different levels and to form three ways of development for different age groups.

The first path concerns the initial stages of work, in which children of elementary grades are involved. Here a series of lessons is implemented to attract them to invention and mastering the methods of inventive work by solving creative problems. During the first class, children perform tasks that help to overcome psychological inertia. During the subsequent classes they get acquainted with such inventive methods as searching for analogues and brainstorming and solve problems using these methods. The result of this stage is the formed schoolchildren' understanding of the meaning and importance of inventive work, as well as mastering the necessary methods of working. At the next stage - in the mid-level, the second trajectory is built. Here, inventive skills are taught through the performance of abstract tasks that adopt solutions with elements of objective novelty; as well as acquaintance with the basic computer-generated graphics required to work with advanced high-tech equipment. For example, to print out an object sing 3-D printer, which was firstly drawn in the Compass program, without which it is impossible to work with this type of equipment? The third trajectory is implemented at the senior level. At this stage, the following become obligatory: schoolchildren mastering of communication online technologies (for remote communication with enterprises); acquaintance with real production facilities during visits to the enterprises in Lipetsk, implementation of innovative projects.

The key aspect of activities implementation in this way is the establishment of the mutual relationship with the technological education of schoolchildren, part of which is teaching inventive work with the real production of enterprises in the region. Moreover, our proposed actions are capable of making such interaction mutually beneficial. Schoolchildren get some unsolved technical problem for development and make an invention. This, firstly, makes the work of students meaningful and practically significant, secondly, it allows learning based on objective examples, and thirdly, it leads to a result important for children - an invention for which a patent is issued. Enterprises, having the opportunity to use the result of the invention, become sponsors of the academic mobility program for young inventors, owing to children can present their work at exhibition areas of various levels - from municipal to international. Visits to enterprises and the possibility of personal communication with representatives of production facilities become an important element at this stage.

Field trips as a form of work in pedagogy have been known for more than a decade (Steenekamp, Van Der Merwe and Mehmedova, 2018), and many issues of their organization are well-developed (Stage, Eriksson and Reestorff, 2019). In this connection, we have defined the classification category of schoolchildren' visits to the enterprise as follows: 1) in terms of goals and content - educational thematic, since schoolchildren get acquainted with the production features of the enterprise; 2) on site - production technological; 3) in terms of participants - intended for an organized homogeneous group of schoolchildren; 4) on site - city, since the enterprises to be planned to visit are located in the city; 5) in terms of travel 


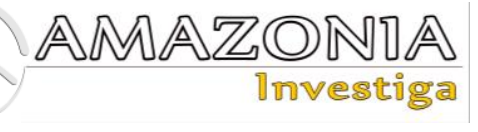

mode - pedestrian; 6) in terms of duration within 60 minutes.

It is objective that visits in teaching invention are part of a multicomponent process and are part of a complex aimed at achieving a common goal (Thompson, 2017). Herewith, in fact, all work with young and middle students can be considered to be pre-visiting to production facility, since the formed understanding of the essence of inventive work and the acquirement of knowledge and skills in the field of invention will be confirmed at the enterprise, since it is there that children will see examples of the invention results (equipment and technologies) and technological problems, the solution of which will lead to new inventions. To conduct an excursion and implement innovative designengineering projects for students at CMIT Novator, we chose an enterprise "LLC Profoborudovanie-L" in Lipetsk. The excursion activity was carried out in several stages.

1) The first stage is preliminary preparation. The excursion preparation solves a number of important issues that determine the success and productivity of all subsequent work. These include: goals and objectives formulation; acquaintance with the site, objects selection for study and determination of the excursion route, determination of information content and methods of working. The purpose of our excursion was to get acquainted with the production of a particular enterprise; tasks study of production equipment; acquaintance with the process of this production; students' search for ideas for their own developments with objective novelty - inventions.

2) Second stage. Excursion tour. The purpose and objectives of the event were explained to the schoolchildren immediately before visiting the enterprise. At the enterprise, during the introductory conversation, before the immediate entering the route, the following was specified: tasks, excursion procedure, reporting form, as well as rules of conduct and safety measures. The work on the excursion route contained the following: students acquaintance with the structure and operation of complex process equipment: advance milling and turning $\mathrm{NC}$ machines; monitoring the assembly process of a roll forming mill. Over a period of work, the students were listening to the explanation of the guide (enterprise's employee) about the features of technical equipment at production, the equipment purpose and the process stages.

3) Third stage. Summing up the excursion results. During the final stage, a conversation was held with the children, summarizing the information obtained and allowing all participants in the excursion to share their impressions.

4) Object development. The next stage was implemented in the classroom of CIMIT Novator. All the observed at the enterprise, the choice of ideas for the collective development of an invention, the search for technical solutions by brainstorming method, the creation of sketches and drawings of a new invention were discussed during subsequent classes. A combined potato digger was taken as the basis for the development, the disadvantage of which was the low productivity of the sorting unit; in this regard, the children were set on suggesting possible ways to increase its operation efficiency. The choice of this machine as an idea for subsequent searches in increasing productivity is justified by the fact that the Lipetsk Region is not only an industrial region, but also an agricultural area. And potatoes cultivation is an important part of crop growing here. In this case, it is necessary not only to grow and take the harvest, but also sort tubers as efficiently as possible, which should be facilitated by the developed invention.

The result of the inventive work at this stage was the improvement of the sorting unit and execution of a patent for a useful model of the combined potato digger (patent $180327 \mathrm{RF}$, IPC A01D17/14 A01D33/08 (2006.01) Combined potato digger / V.P. Tigrov, V.V. Tigrov, A.A. Lazukin, A.P. Shubin, P.P. Klishin, V.A. Chigorsky, M.A. Sokolskikh et al.; applicant and patentee FSBEI of Higher Education Lipetsk State Pedagogical University named after P.P. Semenov-Tyan-Shanskiy - No. 2017121720). A working model of the proposed sorting unit was made at the enterprise "LLC Profoborudovanie-L" and consisted of spirals connected into a single cylindrical structure with different step lengths (from shorter to longer) between the turns in different sections (see Figure 1 and Figure 2). 


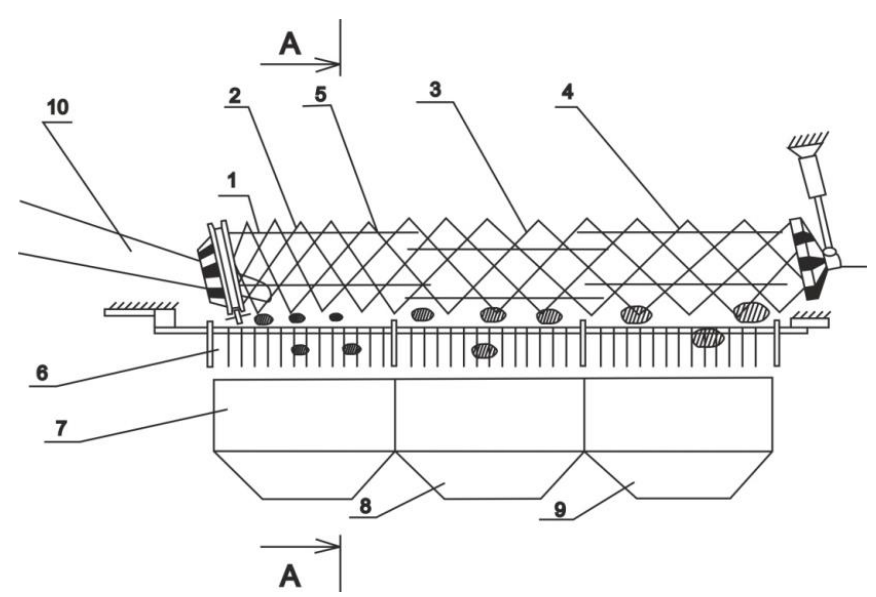

Figure 1. An enlarged view of the sorting unit.

1 - sorting unit, 2 - sorting area for small potatoes, 3 - sorting area for medium potatoes, 4 - sorting area for large, 5 - biters, 6 separation unit, 7 - container for small potatoes, 8 - container for medium potatoes , 9 - container for large potatoes, 10 - loading tray.

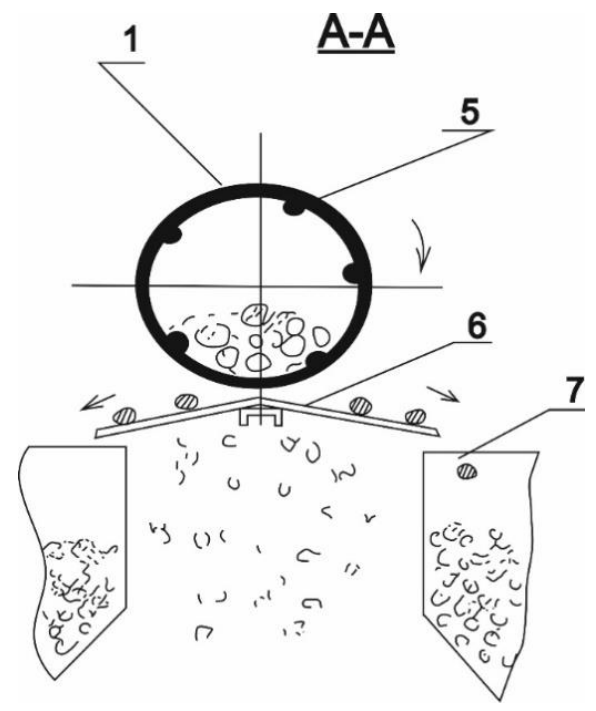

Figure 2. Cross-sectional view of the sorting unit (along arrow A in Figure 1)

The principle of device operation involves the potatoes movement along the spirals axis, where the tubers pour out between its turns in the following sequence: at the beginning they are small - less than $60 \mathrm{~mm}$ in size, then - medium size, and last - all large tubers. Falling down, all the fractions fall into the respective bunkers for small, medium and large potatoes respectively.

The current invention model which had been implemented on the basis of the enterprise - a participant in our project, owing to its support, and was presented at the All-Russian television competition of inventors "The Invention Factory. Ideas for Russia (Moscow)", at the site of the International Salon of Inventions "Archimedes" (Moscow), at the All-Russian exhibition of Scientific and Technical Creativity of the Youth (Moscow). The result of the pedagogical process within the presented field is the inevitable development of divergent thinking of students when they generate more than one solution to the problem under consideration, their ability to creatively process the presented material, offer various options for solving technical problems, which finally forms competencies currently relevant.

\section{Discussion}

Based on the foregoing, we can talk about an objective relationship between the development level of technological education in therm of national situation and the tasks set within the state policy for training specialists in this sphere. In this regard, today, it is fair to say that, on the one hand, the need to change the 


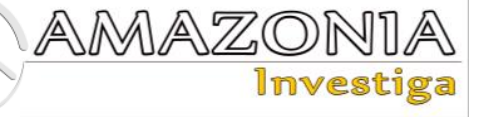

educational paradigm is becoming more acute; on the other hand, the potential of the currently existing industrial concept has not been fully exhausted. Within its framework, important prerequisites are currently being formed that create conditions for the development of divergent thinking and relevant competencies when teaching children to invent and develop their skills in developing objects that have objective novelty.

A practical example of this is the formation of three educational paths (trajectories) which are implemented at the site of the Center for Youth Innovative Creativity "Novator" in Lipetsk. Here, while recruiting elementary grade students into groups for teaching inventions, we are planning the further work with them at subsequent stages of the increasingly complex program. Our experience has shown that teaching inventive work to schoolchildren can be carried out starting from the initial level, for which the first path has been developed. Here, children master the methods of inventive work, and the result is, firstly, the schoolchildren understanding by of the meaning and importance of inventive work; secondly, the experience of using methods such as analog search and brainstorming.

The second way is realized in the middle level, where children perform more complex tasks and learn to analyse technical problems, offering solutions with elements of objective novelty, as well as the basic computer-generated graphics and the skills of using complex equipment such as a 3-D printer. This trajectory prepares schoolchildren for direct inventive work, developing skills in generating and analysing ideas, preparing sketches and drawings on their basis, and performing 3-D mocking-up.

The third way involves working with older students. At this stage, the skill formed in children becomes the mastery of communication on-line technologies, which make it possible to freely and efficiently communicate with representatives of the production sector in the region. And the key element is excursions to production facilities, where children get acquainted with the enterprises of the region, production methods and process lines. And what is really important - with really existing technical problems, solving which, children participate in the development of their own innovative projects. As a result, consistent and methodical work within the existing industrial educational paradigm, which implements the schoolchildren activities on three trajectories, gives them the opportunity to master the necessary skills of inventive work and create objects with objective novelty. In our experiment on teaching invention, this led to the development of schoolchildren ability to generate ideas for updating technical devices, which in practice was implemented in the development of the improved sorting unit for the potato digger, and was obtained a patent for a useful model, where children became part of the author's team. And thanks to the close relationship with the industrial enterprise in Lipetsk, schoolchildren had the opportunity to present this invention at all-Russian and international invention exhibitions and competitions.

The results obtained allow us to state that schoolchildren teaching invention in extracurricular technological education has a positive effect and forms important process competencies necessary in the present-day world. And the proposed algorithm of actions is able to smooth over differences that have arisen currently in the educational system, in the technological field, and become a useful option for school education during the search for more relevant concepts and the formation of new educational paradigms.

\section{Conclusion}

Thus, the analysis of historical materials allowed us to identify the relationship between the trends in the technological education development with the changing situation in the country, as well as the imminent need to change the industrial educational paradigm. However, in case of education system conservatism, the formation of new concepts takes time and a careful approach. Consequently, the emerging problems shall be solved within the established traditions. In this regard, as the main modern trends in technological education, it is possible to emphasize a response the response to the state's request for training specialists with divergent thinking and skill in the field of inventive and innovative activities; as well as building the educational process, starting with the children mastery of the necessary techniques and the simplest process operations at the initial stages of training to the subsequent work mastery using complex process equipment and participation in inventive work at the senior level.

We also identified the prerequisites that allow us to build a model of current technological education, capable to achieve the goals set by 
the state within the existing educational paradigm. These are the need to transfer to innovative design activities in the field of technological education for children and teenagers; accessibility of methods for enhancing creative search and advanced high-tech equipment to students; the possibility for schoolchildren contact with enterprises of the real economy sector. Today, it can be argued that there is a steady interest of children and parents in the development of inventive skill by schoolchildren. This allows forming groups of children studying invention every year within the extended technological education on the basis of CMIT Novator in Lipetsk.

The implemented research gives us the opportunity to form a model of current technological education of schoolchildren within the educational concept being implemented, taking into account the identified trends and prerequisites for further development. As for the developed model, we included sequential work with children on three trajectories: the initial level - the middle level the senior level, and the subject and methodological content for each of them. The organization of the educational process with children made it possible to build a sequence of classes including a system of tasks on each trajectory. On the trajectory of the initial level, tasks are aimed at mastering the methods of inventive work, in the middle level - at performing tasks that involve solutions with elements of objective novelty and studying the basic computer-generated graphics; on the senior level trajectory - at the development of communication online technologies, getting acquainted with production and implementation of innovative projects. It is important that work with children proposes the obligatory use of excursions to industrial enterprises of the city along with the generally accepted methods and forms of work in teaching invention. Therefore, the excursion is an important stage in the inventive work of schoolchildren, linking theoretical knowledge with their practical application. This allows arranging the educational process and effective teaching children to invent, achieving positive results, which is proved by the inclusion of students in the authors' team when obtaining a patent (patent for a combined potato digger) and participation in conferences and exhibitions ("The Invention Factory", "Archimedes", "Scientific and Technical Creativity of the Youth").
Practical work carried out within the framework of the problem posed based on CMIT Novator for several years makes it possible to assert that consistent work with each child from elementary grade to middle and senior grades gives a consistently positive result in the formation of inventive skill, and in addition, important inventive skills and thinking divergence. As a result, it can be said that. Using the potential of extracurricular technological education for schoolchildren, within which it is possible to teach children to invention, is able to smooth out the growing problems of the existing industrial educational paradigm in the "Technology" subject. The systematic training of schoolchildren in this system complicating and extending the program during the transition from the educational trajectory of the primary level to the middle and senior levels, the use of current methodological, informational and technical capabilities, as well as close relationship with the enterprises of the region and the solution of objective problems, normally gives a positive result during the formation of divergent thinking, which translates into the child's ability to generate a variety of ideas for improving technical objects and forming competencies currently relevant.

\section{References}

Ardura, D., \& Pérez-Bitrián, A. (2019). Motivational pathways towards academic achievement in physics \& chemistry: A comparison between students who opt out and those who persist. Chemistry Education Research \& Practice, 20, 618-632. https://doi.org/10.1039/C9RP00073A

Ankiewicz, P.J. (2019). Andrew Feenberg: Implications of critical theory for technology education. In J.R. Dakers, J. Hallstrem \& M.J. De Vries (Eds.). Reflections on Technology for Educational Practitioners: Philosophers of Technology Inspiring Technology Education. Boston, MA: Brill.

Botleng, V.J., Brunel, S., \& Girard, P. (2019). Learning through design and make: Producing originally thought-out products versus producing pre-designed products downloaded from data files. In S. Pulé \& M.J. De Vries (Eds.). Proceedings PATT 37, Developing a Knowledge Economy through Technology and Engineering Education, Msida, Malta,. Msida: University of Malta. https://www.iteea.org/File.aspx?id=157700\&v= e94e5d51

Bushueva, V.V., \& Bushuev, N.N. (2018). Comparative analysis of domestic and foreign activation methods of technical creativity. 


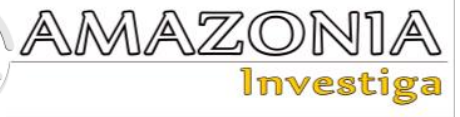

Advances in Economics, Business and Management Research (Proceedings of the 2018 International Conference on Economy, Management And Entrepreneurship - ICOEME 2018), 70, 31-35. https://doi.org/10.2991/icoeme-18.2018.6

Chai C.S., Jong, MS-Y., Yin, H-B., Chen, M., \& Zhou, W. (2019). Validating and modelling teachers' technological pedagogical content knowledge for integrative science, technology, engineering and mathematics education. Educational Technology \& Society, 22(3), 61-73.

Cropley, D., \& Cropley, A. (2010). Recognizing and fostering creativity in technological design education. International Journal of Technology and Design Education, 20(3), 345-358.

Dakers, J.R. (Ed.) (2006). Defining Technological Literacy: Towards an Epistemological Framework. New York: Palgrave Macmillan.

Danilaev, D.P., \& Malivanov, N.N. (2020). Technological education and engineering pedagogy. The Education and Science Journal, 22(3), 55-82. https://doi.org/10.17853/19945639-2020-3-55-82

Dessauer, F. (1959). What Is The Human? The Four Questions of Immanuel Kant. Frankfurt am Main:

Knecht.

https://www.semanticscholar.org/paper/Was-istder-Mensch-\%3A-die-vier-Fragen-des-

Immanuel-

Dessauer/e2151a5e1cba3a87eea04b861d97f7e4 310deab2

Dessauer, F. (1983). Philosophy in its proper sphere. In C. Mitcham and R. Mackey (Eds.). Philosophy and Technology: Readings in the Philosophical Problems of Technology (pp. 317-334). New York: Free Press. https://books.google.ru/books?id=R5X_xpis2Qs $\mathrm{C} \&$ printsec $=$ frontcover $\& \mathrm{hl}=\mathrm{ru} \&$ source $=\mathrm{gbs} \_\mathrm{bo}$ ok_other_versions $\# \mathrm{v}=$ onepage $\& \mathrm{q} \& \mathrm{f}=$ false Dessauer, F. (1956). Slreit in die Technik [Controversy over Technology]. Frankfurt am Main: Knecht. https://katalog.ub.tubraunschweig.de/vufind/Search2Record/018593 461

Duggan, R. (1996). Promoting innovation in industry, government and higher education. Long Range Planning, 29(4), 503-513. https://doi.org/10.1016/0024-6301(96)00042-8 Gordon, E.W., Aber, L., \& Berliner, D. (2012). Changing Paradigms for Education: From Filling Buckets to Lighting Fires. To Cultivation of Intellective Competence. Princeton, NJ: Educational Testing Service. https://www.ets.org/Media/Research/pdf/gordon _gordon_berliner_aber_changing_paradigms_ed ucation.pdf
Hallström, J. (2020). Embodying the past, designing the future: Technological determinism reconsidered in technology education. International Journal of Technology and Design Education, 28(1), 1-15. https://doi.org/10.1007/s10798-020-09600-2

Heidegger, M. (1977). The Question Concerning Technology, and Other Essays. Trans. by W. Lovitt. New York \& London: Garland

Publ. https://monoskop.org/images/4/44/Heidegger Martin_The_Question_Concerning_Technology _and_Other_Essays.pdf

Hrybiuk, O. (2019). Improvement of the educational process by the creation of centers for intellectual development and scientific and technical creativity. In A. Hamrol, A. Kujawińska \& M. Barraza (Eds.). Advances in Manufacturing II. MANUFACTURING 2019. Lecture Notes in Mechanical Engineering. Cham: Springer. https://doi.org/10.1007/978-3030-18789-7_31

Hursen, C. (2017). The effect of a school based outdoor education program on visual arts teachers' success and self-efficacy beliefs. South African Journal of Education, 37(3), 1-17. https://doi.org/10.15700/saje.v37n3a1395 Ihde, D. (2006). The designer fallacy and technological imagination. In J.R. Dakers (Ed.). Defining Technological Literacy: Towards an Epistemological Framework. New York: Palgrave MacMillan. https://doi.org/10.1057/9781403983053_9 Kachnev, V.I. (Ed.) (1990). Creative Technical and Design Activities in the Labor Training of Schoolchildren: Method. Recommendation. Tashkent:

UzNIIPN. https://search.rsl.ru/ru/record/01001564295

Kaner, V.F. (Ed.) (2016). Problems of Technical Creativity. Ufa: Aeterna. https://search.rsl.ru/ru/record/01008733077 Kolotilov, B.B. (1989). Extracurricular Work on Technology and Labor. Kirov: Volgo-Vyat Publishing.

https://search.rsl.ru/ru/record/01001512185

Kondratiev, A., Rudneva, O., \& Tolstenko, A. (2021). The strange case of Fyodor Dostoevsky and Robert Stevenson in the Victorian Age: A protest against the depersonalization. Amazonia Investiga, 10(41), 74-84. https://doi.org/10.34069/AI/2021.41.05.7

McLain, M., Irving-Bell, D., Wooff, D., Morrison-Love, D. (2019). How technology makes us human: Cultural historical roots for design and technology education. The Curriculum Journal, 30(4), 464-483. https://doi.org/10.1080/09585176.2019.1649163 
Mitcham, C. (1994). Thinking through Technology. The Path between Engineering and Philosophy. Chicago: Chicago University Press. Nesterenko, A.A., Terekhova, G.V. (2017). Creation of the environment for the development of inventive abilities in subjects of education. Espacios, 38(40), 28. https://www.revistaespacios.com/a17v38n40/a1 7v38n40p28.pdf

Nigmatov, Z.G., \& Nugumanova, I.N. (2015). Methods for developing technological thinking skills in the pupils of profession-oriented schools. Asian Social Science, 11(8), 207-214. http://doi.org/10.5539/ass.v11n8p207

Nikulin, S.K. (1994). Development of technical creativity of vocational education students in the period of transition to the market: The managerial aspect ( $\mathrm{PhD}$ thesis). Institute of General Education, Moscow, https://search.rsl.ru/ru/record/01000102672

Portnova, T.V. (2016). Structural features of theatrical excursions (methodology based on theatre museum expositions. IEJME: Mathematics Education, 11(8), 2963-2973. https://www.iejme.com/article/structuralfeatures-of-theatrical-excursions-methodologybased-on-theatre-museum-expositions

Sasova, I.A. (2011). Technological education or labor training? Russian Education and Society, 53(6), 49-65. https://doi.org/10.2753/RES10609393530604

Skrbina, D. (2014). German metaphysical insights Dessauer, Juenger, Heidegger. In D. Skrbina, (2014). Metaphysics of Technology (Ser.: Routledge Studies in Social and Political Thought, vol. 94) (pp. 70-93). New York: Routledge.

https://doi.org/10.4324/9781315879581

Skytt-Larsen, C.B. (2018). The influence of the early formation of human and social capital on inventiveness: Perspectives from a Swedish case study. Geojournal, 83(6), 1181-1192. https://doi.org/10.1007/s10708-017-9826-3

Smirnova, E. (2018). Control capability of environmental safety in the context of green construction paradigm. Espacios, 39(22), 40. https://www.revistaespacios.com/a18v39n22/a1 8v39n22p40.pdf

Solé Blanch, J. (2020). El cambio educativo ante la innovación tecnológica, la pedagogía de las competencias y el discurso de la educación emocional [The educational change in front of the technological innovation, the pedagogy of competences and the discourse of the emotional education. A critical approach]. Una Mirada Crítica Ediciones Universidad de Salamanca, 32(1), 101-121. http://doi.org/10.14201/teri.20945

Stage, C., Eriksson, B., \& Reestorff, C.M. (2019). Understanding cultural participation through participation - inventiveness, multivalence and epistemic modernization. Cultural Trends, 29(1), 1-16. https://doi.org/10.1080/09548963.2019.1692183 Steenekamp, K., Van Der Merwe, M., \& Mehmedova, A.S. (2018). Enabling the development of student teacher professional identity through vicarious learning during an educational excursion. South African Journal of Education, 38(1), 1-8. https://doi.org/10.15700/saje.v38n1a1407

Sundqvist, P. (2020). Technological knowledge in early childhood education: Provision by staff of learning opportunities. International Journal of Technology and Design Education, 30, 225-242. https://doi.org/10.1007/s10798-01909500-0

Susanto, R., Rachmadtullah, R., \& Rachbini, W. (2020). Technological and pedagogical models: Analysis of factors and measurement of learning outcomes in education. Journal of Ethnic and Cultural Studies, 7(2), 1-14. http://doi.org/10.29333/ejecs/311

Thayer-Bacon, B.J. (2019). Redefining work and education in the technological revolution. Studies in Philosophy and Education, 38, 581-590. https://doi.org/10.1007/s11217-01909649-0

Thompson, K. (2017). Changing Education Paradigms. Revise Sociology, https://revisesociology.com/2017/07/30/kenrobinson-changing-education-paradigms/

Tigrov, V., \& Negrobova, L. (2018). Nature excursion as a means of developing schoolchildren's creative thinking and solving inventive problems. International Journal of Civil Engineering and Technology, 9(11), 2561-2568.

https://www.researchgate.net/publication/32973 9057_Nature_excursion_as_a_means_of_develo ping_schoolchildren's_creative_thinking_and_s olving_inventive_problems

Tolstenko, A., Baltovskij, L., \& Radikov, I. (2019). Chance of civic education in Russia. Sage Open, 9(3), 1-16. https://doi.org/10.1177/2158244019859684 